\title{
Prostaglandin F2 $\alpha$ as ovulatory stimulus in dairy cows and buffaloes raised in the Amazon biome
}

\section{Prostaglandina F2 $\alpha$ como estímulo ovulatório em vacas e búfalas leiteiras criadas no bioma Amazônia}

\author{
Luiz Francisco Machado Pfeifer ${ }^{1 *}$; Natália Avila de Castro²; Jamyle Pereira \\ Cestaro3; Augusto Schneider $^{4}$
}

\section{Highlights}

Treatment of crossbred dairy cows with $\mathrm{PGF}_{2} \alpha$ tended to increase synchronization of ovulation. $\mathrm{PGF}_{2} \alpha$ hastens ovulation in crossbred dairy cows but not in dairy buffaloes.

$\mathrm{PGF}_{2} \alpha$ has a role in the ovulation process in dairy cows that is unrelated to its luteolytic effect.

\begin{abstract}
This study evaluated the effect of a prostaglandin $F_{2 \alpha}$ (PGF) analogue as an ovulatory stimulus in dairy cows and buffaloes raised in the Amazon biome. To this end, three experiments were performed in the state of Rondônia, located in the Amazon biome. In Experiment 1, 22 lactating dairy buffaloes received $2 \mathrm{mg}$ of intramuscular (I.M.) estradiol benzoate (EB) on day 0 and an intravaginal progesterone-releasing device (CIDR) from day 0 to day 9 of the protocol. On days 8 and 9, all cows were given $150 \mu \mathrm{g}$ of I.M. d-cloprostenol (PGF analogue). On day 10, buffaloes were divided into two groups to receive $150 \mu \mathrm{g}$ of PGF (PGF group, $n=8$ ) or no treatment (CTL group, $n=14$ ), respectively. In Experiment 2, 16 lactating crossbred dairy cows (Holstein $x$ Gir) received $2 \mathrm{mg}$ of EB on day 0 and a CIDR insert from day 0 to day 8. On days 7 and 8, all cows were given $150 \mu \mathrm{g}$ of d-cloprostenol. On day 9, cows were divided into two groups to receive $150 \mu \mathrm{g}$ of d-cloprostenol (PGF group, $n=8$ ) or no treatment (CTL group, $n=8$ ), respectively. In Experiment 3, 16 lactating crossbred dairy cows (Holstein x Gir) were handled and treated similarly as in Experiment 2, although cows did not receive d-cloprostenol on day 8 . Single-point outcome variables were analyzed using one-way analysis of variance (ANOVA), while proportions with dichotomous outcomes were analyzed with the chi-square test. In Experiment 1 , there was no difference $(P=0.30)$ in the ovulation rate between groups, and, on average, $68 \%$ of the buffaloes ovulated. Moreover, the treatment did not affect the interval to ovulation $(P=0.61)$ nor the diameter of the preovulatory follicle $(P=0.47)$. As for Experiment 2, only one cow, from the $P G$ group, did not
\end{abstract}

1 Pesquisador A, Empresa Brasileira de Pesquisa Agropecuária, EMBRAPA, Brazilian Agricultural Research Corporation, Porto Velho, RO, Brasil. E-mail: luizfembrapa@gmail.com

2 Dra em Veterinária, Universidade Federal de Pelotas, UFPel, Pelotas, RS, Brasil. E-mail: nataliavetufpel@gmail.com

${ }^{3}$ Discente do Curso de Mestrado do Programa de Pós-Graduação em Sanidade e Produção Animal, PPGESPA, Universidade Federal do Acre, UFAC, Rio Brasil, AC, Brasil. E-mail: jamyle_cestaro@hotmail.com

4 Prof. Dr., Programa de Pós-Graduação em Veterinária, UFPel, Pelotas, RS, Brasil. E-mail: augustoschneider@gmail.com

* Author for correspondence

Received: Mar. 27, 2020 - Approved: July 14, 2020 
ovulate. There were no differences between the CTL and PG groups $(P=0.69)$ in the moment of ovulation, which occurred in average $82 \mathrm{~h}$ after CIDR removal. Finally, in Experiment 3, cows treated with PGF ovulated earlier than those in the CTL group ( $62.5 \pm 5.8$ and $94.5 \pm 13.5 \mathrm{~h}$, respectively; $P=0.05)$. Collectively, these results suggest that PGF hastens ovulation in lactating dairy cows, whereas no effect was observed in dairy buffaloes.

Key words: Buffaloes. Cattle. Hormonal protocol. Milk. Ovulation. North region.

\section{Resumo}

O objetivo deste estudo foi avaliar o efeito de um análogo de prostaglandina F2 $\alpha$ (PGF) como indutor ovulatório em vacas leiteiras e búfalas. Para este fim, três experimentos foram realizados no estado de Rondônia, localizado no bioma Amazônia. No Experimento 1, 22 búfalas leiteiras em lactação receberam $2 \mathrm{mg}$ de benzoato de estradiol (EB) im, no Dia 0 e um dispositivo intravaginal de liberação de progesterona (CIDR) do Dia 0 ao Dia 9 do protocolo. Nos Dias 8 e 9, todas as vacas receberam 150 $\mu$ g de d-Cloprostenol

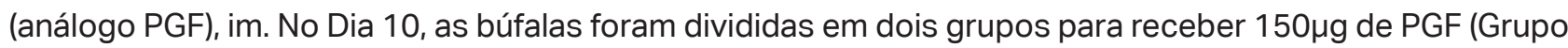
PGF, $n=8$ ) ou nenhum tratamento (Grupo $C T L, n=14$ ). No experimento 2, 16 vacas leiteiras mestiças (Holandês $x$ Gir) receberam $2 \mathrm{mg}$ de EB no Dia 0 e um dispositivo intravaginal (CIDR) do Dia 0 ao Dia 8. Nos Dias 7 e 8 todas as vacas receberam 150 $\mathrm{gg}$ de d-Cloprostenol. No Dia 9, as vacas foram divididas em dois grupos para receber $150 \mu \mathrm{g}$ de d-Cloprostenol (Grupo PGF, $\mathrm{n}=8$ ) ou nenhum tratamento (Grupo $\mathrm{CTL}, \mathrm{n}$ = 8). No Experimento 3, 16 vacas leiteiras mestiças (Holandês x Gir) foram tratadas da mesma forma que no Experimento 2, porém, as vacas não receberam d-Cloprostenol no Dia 8. Variáveis quantitativas foram analisados por análise de variância - one-way ANOVA e variáveis dicotômicas foram analisados pelo teste do qui-quadrado. No Experimento 1, não houve diferença $(P=0,30)$ na taxa de ovulação entre os grupos, em média $68 \%$ das búfalas ovularam após o tratamento. Além disso, não houve diferença entre os grupos no intervalo de ovulação $(P=0,61)$ e no diâmetro do folículo pré-ovulatório $(P=0,47)$. No Experimento 2 , apenas uma vaca do Grupo PG não ovulou. Não houve diferenças no intervalo de ovulação entre os grupos CTL e PG $(P=0,69)$. Em média, a ovulação ocorreu 82 horas após a remoção do CIDR. No Experimento 3 , vacas tratadas com PGF ovularam antes do Grupo CTL ( $62,5 \pm 5,8$ vs $94,5 \pm 13,5 h ; P=0,05)$. Coletivamente, esses resultados sugeriram que a PGF antecipa a ovulação em vacas leiteiras em lactação, porém seu efeito não foi observado em búfalas.

Palavras-chave: Inseminação artificial. Gado. Concepção. Gametas.

\section{Introduction}

Since the 1960s, the cattle herd raised in the Amazon biome has increased from 5 million to more than $70-80$ million heads. Around $80 \%$ of the deforested areas of the Amazon forest have been covered by pasture (i.e., approximately 900000 $\mathrm{km}^{2}$ ). Cattle expansion occurs in the new agricultural frontier areas, from the Eastern Brazilian Amazon (i.e., states of Maranhão and Pará), through the Southern Brazilian Amazon (i.e., states of Tocantins, Mato Grosso, and Rondônia; Piketty, Poccard-Chapuis, Veiga \& Tourrand, 2002). Currently, farmers from this region are concerned about their negative ecological impacts, as sustainable livestock intensification is still a challenge in the Amazon 
biome. Dairy cattle compose $22 \%$ of the herd raised in this region and, from 1974 to 2015, the states of Para and Rondônia increased their dairy herd at a yearly rate of $6.92 \%$ and $15.15 \%$, respectively (Instituto Brasileiro de Geografia e Estatistica [IBGE], 2016). However, the milk yield and reproductive performance of dairy cattle raised in the Brazilian Amazon have been characterized by a low productivity. In that regard, the synchronization of ovulation to enable timed artificial insemination (TAI) is an important technology implemented to increase the profitability of commercial dairy farms of cattle and buffaloes. TAl eliminates the need for heat detection, which is a major limitation to the success of artificial insemination. This is especially the case in buffaloes because of their high incidence of subestrus (i.e., silent estrus), which is perhaps the most important factor leading to poor reproductive efficiency (Kanai \& Shimizu, 1983; Madan \& Prakash, 2007). Moreover, the concentration of estradiol-17 $\beta$ in the blood of buffaloes during the follicular phase is lower than that of cows (Avenell, Seepudin, \& Fletcher, 1985; Kanai, Abdul-Latief, Ishikawa, \& Shimizu, 1990; Roy \& Prakash, 2009). The lower serum estradiol concentration may be associated to the lesser intensity of the estrus exhibited by buffaloes (Perera, 2011). Thus, artificial insemination (Al) after the detection of estrus is not feasible in this species.

There are several efficient estradiolprogesterone based synchronization protocols for dairy cows (Cavalieri, Hepworth, Parker, Wright, \& Macmillan, 2003; Melo et al., 2016). Such protocols, with some adjustments to the particularities of the species, have been tested and commercially applied in buffaloes (Oliveira et al., 2001; Camelo, Ribeiro, \& Silva, Souza \& Vale, 2002; Baruselli \& Carvalho, 2005;
Rolim et al., 2009). Many protocols include the use of a source of progesterone associated with estradiol benzoate (EB) at the beginning of treatment to induce the emergence of a new follicular wave, as well as a prostaglandin analog to promote the regression of the corpus luteum (CL) and an ovulatory stimulus, such as $\mathrm{GnRH}$, estradiol cypionate (ECP), or estradiol benzoate (EB). Notably, GnRH has been the most commonly recommended ovulation inducer for buffaloes (Carvalho et al., 2007; Neglia et al., 2008).

Although prostaglandin $F_{2 \alpha}$ (PGF) analogues are widely used in TAI protocols due to their luteolytic action, it is known that PGF also plays a role in the ovulatory process (Silva \& Reeves, 1985; Algire, Srikandakumar, Guilbault, \& Downey, 1992; Weems, Weems, \& Randel, 2006; Bridges \& Fortune, 2007). Furthermore, previous studies have demonstrated that the exogenous application of d-cloprostenol (a PGF analogue) induces the first ovulation in beef heifers (Pfeifer et al., 2009; Leonardi et al., 2012). Recently, it was shown that PGF hastens ovulation in beef heifers and postpartum cows, resulting in pregnancy rates similar to those obtained using estradiol esters (Pfeifer et al., 2014). Despite the evidences that exogenous PGF can be used as an ovulation inducer in cattle, the effectiveness of PGF has not been tested in crossbred dairy cows and dairy buffaloes.

Based on these considerations, the present study evaluated the effect of d-cloprostenol as an ovulation inducer in crossbred dairy cows and buffaloes. The hypothesis tested was that a PGF analogue, administered $24 \mathrm{~h}$ after the removal of the exogenous source of progesterone, is able to induce ovulation in a synchronized manner in dairy cows and buffaloes. 


\section{Materials and Methods}

The Committee for Ethics in Animal Experimentation from the Brazilian Agricultural Research Corporation (Embrapa - Rondônia) approved all procedures performed in this experiment (F.02/2014).

\section{Experiment 1}

This experiment was performed at the experimental research farm of Embrapa Rondônia, located in Presidente Médici, RO,

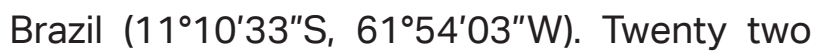
lactating crossbred dairy buffaloes (mainly Murrah), 4 to 13 years old, maintained on pasture (Brachiaria brizantha cv. Marandu) with ad libitum access to salt and water were enrolled in this study.

The experimental design is shown in Figure 1A. On Day 0 , buffaloes were treated with $2 \mathrm{mg}$ of estradiol benzoate (EB; Bioestrogen ${ }^{\circledast}$, Biogénesis-Bagó, Curitiba, Brazil) intramuscularly (IM) plus an intravaginal progesterone-releasing device (CIDR ${ }^{\oplus ;} 1.9$ g progesterone, Pfizer Animal Health, São Paulo, Brazil), which remained until Day 9. On Days 8 and 9 buffaloes were given 150 $\mathrm{\mu g}$ of d-Cloprostenol (PGF analogue Croniben ${ }^{\circledast}$, Biogénesis-Bagó, Curitiba, Brazil), IM. On Day 10 , buffaloes were assigned into two groups to receive $150 \mu$ g of PGF (PGF Group, $n=14$ ), or no treatment (CTL Group, $\mathrm{n}=8$ ).

A) Dairy buffaloes (PGF D8 D9)

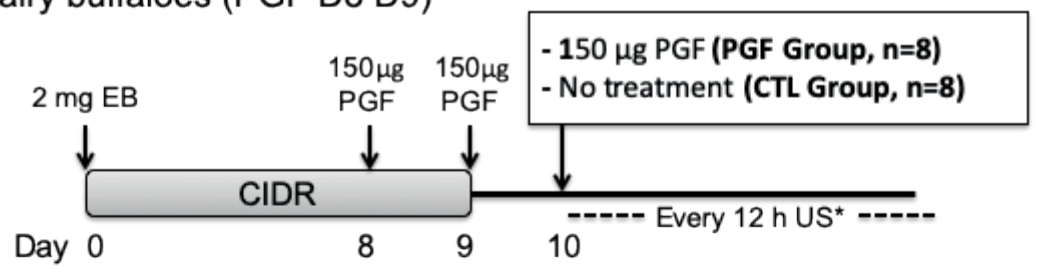

B) Dairy cows (PGF D7 D8)

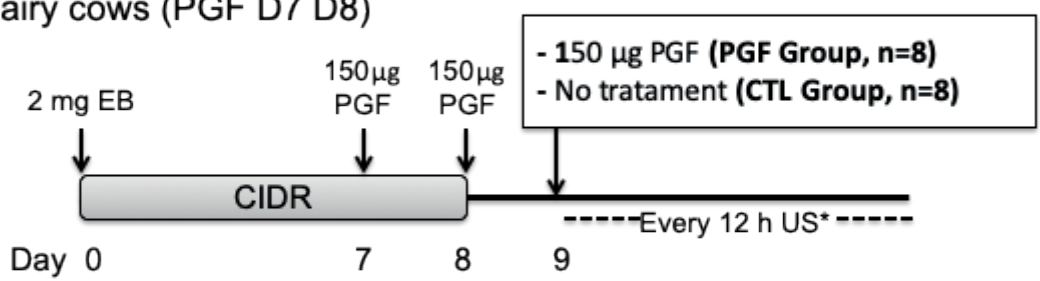

C) Dairy cows (PGF D7)

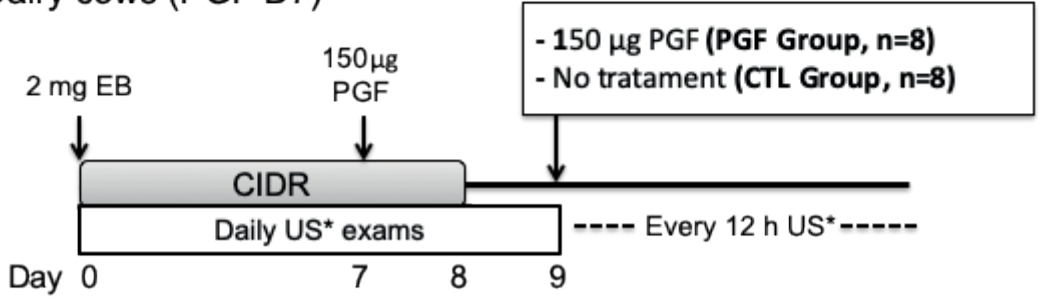

Figure 1. Experimental design used for $(A)$ dairy buffaloes $(n=16)$ in Experiment 1, (B) dairy cows $(n=16)$ in Experiment 2, and $(C)$ dairy cows in Experiment $3(n=16)$.

$\mathrm{EB}=$ Estradiol Benzoate; $\mathrm{PGF}=$ Prostaglandin $\mathrm{F}_{2} \alpha$; US = Ultrasound. 


\section{Experiment 2}

This study was performed at the experimental research farm of Embrapa Rondônia (Brazilian Agricultural Research Corporation, Rondônia, Brazil; 0848'12" S, $\left.63^{\circ} 50^{\prime} 56^{\prime \prime} \mathrm{W}\right)$. Sixteen crossbred dairy cows (Holstein x Gir) were used. Cows were kept in an outdoor grazing system (Brachiaria brizantha cv. Marandu pasture) and were fed a supplemental corn and soybean meal with ad libitum access to mineral salt and water.

Experimental design is shown in Figure 1B. On Day 0, all cows were treated with $2 \mathrm{mg}$ of EB, IM, plus a CIDR device, which remained until Day 8. On Days 7 and 8 cows were given $150 \mu \mathrm{g}$ of d-Cloprostenol IM. On Day 9, cows were assigned into one of two groups to receive $150 \mu \mathrm{g}$ of PGF (PGF Group, $\mathrm{n}=8$ ) or no treatment (CTL Group, $\mathrm{n}=8$ ).

\section{Experiment 3}

This study was performed in the same experimental research farm as in Experiment 2. Sixteen crossbred dairy cows (Holstein $x$ Gir) were used and the experimental design is shown in Figure 1C. Cows were handled and treated similarly as in Experiment 2, however cows did not receive d-Cloprostenol on Day 8. On Day 9, cows were assigned into one of two groups to receive $150 \mu \mathrm{g}$ of PGF (PGF Group, $\mathrm{n}$ $=8$ ) or no treatment (CTL Group, $n=8$ ).

\section{Ultrasonographic examinations and definitions}

Prior to the beginning of the experiments, all females were examined by transrectal ultrasonography (SIUI CTS-900, equipped with a $5 \mathrm{Mhz}$ linear-array transducer, Guangdong, China) twice, 7 to $11 \mathrm{~d}$ apart, to confirm the presence of a CL or DF and to evaluate the degree of uterine tonus, to ensure that all cows had resumed postpartum ovarian activity. Only females in which a CL or DF was detected in at least one of the examinations were included in this study. Transrectal ultrasonographic examinations were also used to distribute cows homogeneously between groups, according to the diameter of the dominant follicle at CIDR removal in all experiments. Thus, we ensure that groups had similar follicular maturity at the time of the treatments.

In Experiments 1 and 2, ultrasound examinations were performed every $12 \mathrm{~h}$ from CIDR removal to ovulation or, in the absence of ovulation, up to six days after CIDR removal. In Experiment 3, cows were scanned daily to monitor ovarian follicular development from Day 0 to Day 9 in order to perform data normalization of follicular growth (Garcia \& Salaheddine, 2001). At each scanning session, a sketch of each ovary was made and the diameter and location of follicles $\geq 3 \mathrm{~mm}$ in diameter were recorded following procedures described elsewhere (Ginther, Knopf, \& Kastelic, 1989). The day of wave emergence was defined retrospectively as the day when the dominant follicle was first detected at a diameter of 4 to $5 \mathrm{~mm}$ (Ginther et al., 1989). After CIDR removal, ultrasound examinations were performed every $12 \mathrm{~h}$, similarly as in Experiments 1 and 2. Ovulation was defined as the disappearance (from one scanning session to the next) of a previously identified follicle $\geq 8$ $\mathrm{mm}$ in diameter (Martinez, Kastelic, Bo, Caccia, \& Mapletoft, 2005). The synchronized ovulation rate was calculated by the proportion of females ovulating within an interval of 24 hours. Therefore, buffaloes in experiment 1 were considered synchronized when the ovulations 
occurred between 78 and 102 hours after CIDR removal. Cows in experiments 2 and 3 were considered synchronized when the ovulations occurred between 60 and 84 hours after CIDR removal.

\section{Blood sampling and Progesterone analysis}

Blood samples were daily collected, from CIDR removal until ovulation detection, by caudal venipuncture into $10 \mathrm{~mL}$ tubes (Becton Dickinson Vacutainer Systems, Franklin Lakes, NJ, USA) with EDTA. Blood samples were centrifuged (1500 $\mathrm{xg}$ for $15 \mathrm{~min}$ ), and plasma was harvested and stored at $-20{ }^{\circ} \mathrm{C}$. Plasma progesterone concentrations were assayed with a solid-phase radioimmunoassay (Rawlings, Jeffcoate, \& Rieger, 1984). Progesterone was analyzed after extraction with $3 \mathrm{~mL}$ hexane from $200 \mathrm{~mL}$ aliquots of plasma. The intra-assay coefficients of variation were $14.3 \%$ and $9.2 \%$ for low $(0.24$ $\mathrm{ng} / \mathrm{mL}$ ) and high (0.93 $\mathrm{ng} / \mathrm{mL}$ ) progesterone concentrations, respectively.

\section{Statistical analysis}

All statistical analyses were performed using Statistical Analysis System Institute [SAS Institute] (1998). Single-point outcome variables (time of ovulation and diameter of pre-ovulatory follicle) were analyzed using analysis of variance - one-way ANOVA, and the means were compared between groups using Tukey's post hoc test. Proportions with dichotomous outcomes (ovulation rate and synchronized ovulation rate) were analyzed using the Chi-square test.

Analyses of serum progesterone concentration involving repeated measures over time were compared by analysis of variance for repeated measures using the MIXED procedure to evaluate the main effects of treatment, time (sampling period), and their interaction (treatment vs. time). When the interaction was significant, means were compared among treatments using the Tukey post-hoc test adjustment to account for multiple comparisons in the model.

Differences among groups were considered statistically significant when the probability (P-value) was less than or equal to 0.05 . P-values between 0.05 and 0.1 were considered as a trend.

\section{Results}

\section{Experiment 1}

The ovarian responses are shown in Table 1. There was no difference in ovulation rate between the two groups $(P=0.30)$, wherein the overall ovulation rate was of $68 \%$. Similarly, the progesterone concentration after the removal of the CIDR was not different between groups ( $P=0.94$; Figure 2A). Dairy buffaloes in both experimental groups had a serum progesterone concentration below $1 \mathrm{ng} / \mathrm{mL}$ after CIDR removal. Furthermore, the interval to ovulation was not different between groups $(P=0.61)$ and was, on average, $89 \mathrm{~h}$ after CIDR removal. No difference in the diameter of the preovulatory follicle was detected between groups $(P=0.47)$. Although PGF treated dairy buffaloes appeared to ovulate more synchronously, there was no difference $(P>0.05)$ between groups in the distribution of ovulation (Figure 3A). After CIDR removal, buffaloes treated with PGF ovulated from 66 to $102 \mathrm{~h}$, while control buffaloes ovulated from 54 to $126 \mathrm{~h}$. 
Table 1

Ovarian responses of dairy buffaloes (Experiment 1) and cows (Experiments 2 and Experiment 3) exposed to an estradiol-progesterone based protocol and treated (PGF group) or not (CTL group) with PGF $24 \mathrm{~h}$ after CIDR removal

\section{Experimental Group}

Ovarian responses CTL

PGF

P-values

Experiment 1 - Buffaloes (PGF D8 D9)

Ovulation rate $78.6 \%(11 / 14)$

$62.5 \%(5 / 8)$

0.41

Synchronized ovulation rate

(78-102 h after CIDR removal)

$72.7 \%(8 / 11) \quad 80 \%(4 / 5) \quad 0.75$

Interval to ovulation ( $\mathrm{h} \pm \mathrm{SE}$ )

$89.0 \pm 5.1$

$85.2 \pm 9.5$

0.69

Preovulatory follicle diameter $(\mathrm{mm} \pm \mathrm{SE})$

$15.23 \pm 0.8$

$15.3 \pm 0.9$

0.8

Experiment 2 - Cows (PGF D7 D8)

Ovulation rate

$100 \%(8 / 8)$

$87.5 \%(7 / 8)$

0.3

Synchronized ovulation rate

(60-84 $\mathrm{h}$ after CIDR removal)

$87.5 \%(7 / 8) \quad 85.7 \%(6 / 7) \quad 0.9$

Interval to ovulation ( $\mathrm{h} \pm \mathrm{SE}$ )

$84.0 \pm 5.7$

$80.0 \pm 6.1$

0.69

Preovulatory follicle diameter $(\mathrm{mm} \pm \mathrm{SE})$

$14.1 \pm 0.5$

$13.9 \pm 0.6$

0.80

Experiment 3 - Cows (PGF D7)

Ovulation rate

$100 \%(8 / 8) \quad 100 \%(8 / 8)$

1

Synchronized ovulation rate

(60-84 $\mathrm{h}$ after CIDR removal)

$37.5 \%(3 / 8)$

$85.7 \%(6 / 8)$

0.1

Interval to ovulation ( $\mathrm{h} \pm \mathrm{SE}$ )

$94.5 \pm 10.4$

$64.5 \pm 10.4$

0.05

Preovulatory follicle diameter $(\mathrm{mm} \pm \mathrm{SE})$

$14.9 \pm 0.76$

$16.0 \pm 0.76$

0.34 
(A) Dairy buffaloes

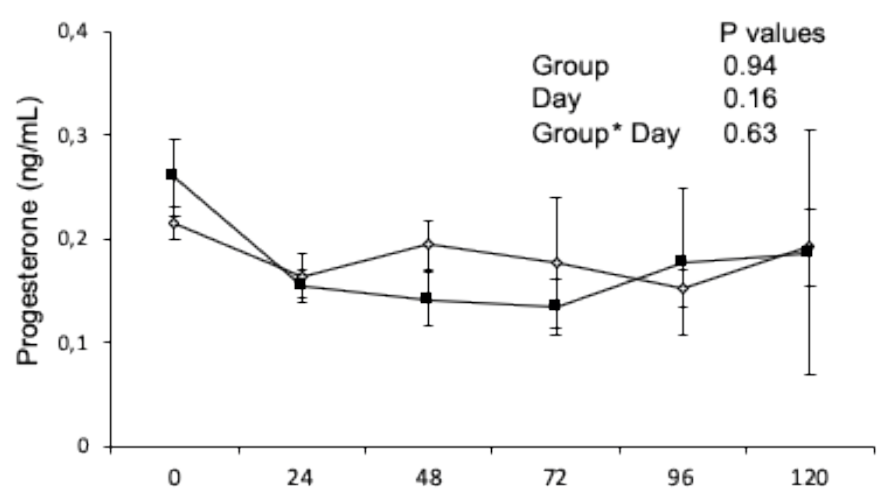

(B) Dairy cows

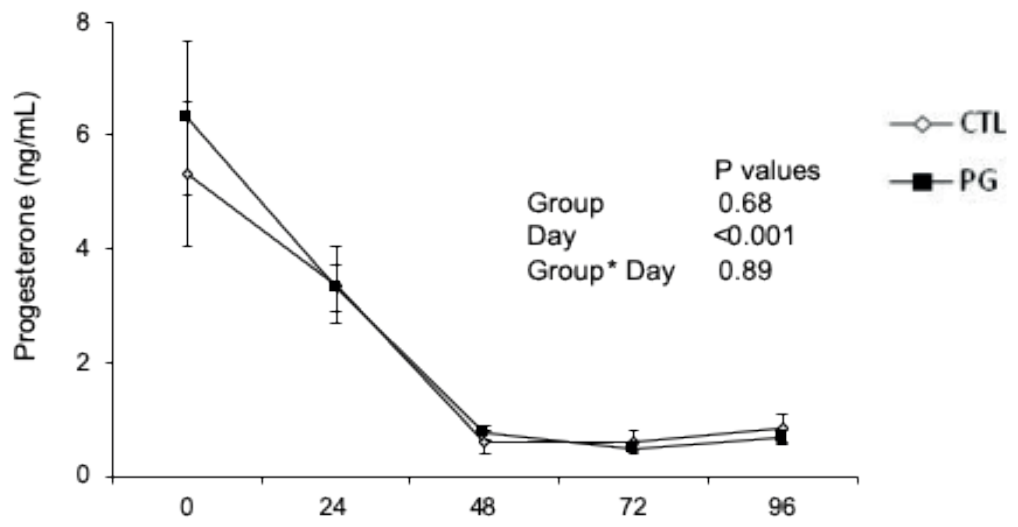

(C) Dairy cows

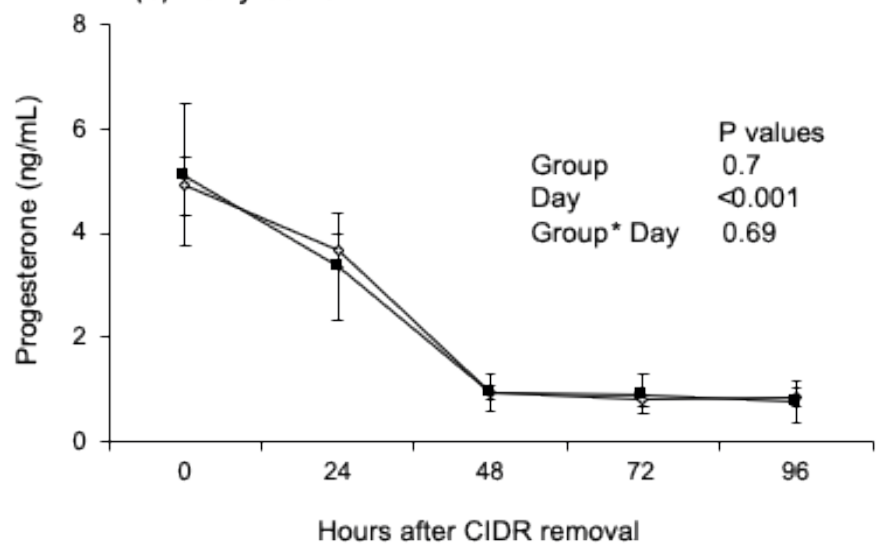

Figure 2. Serum progesterone concentrations in dairy $(A)$ buffaloes and ( $\mathrm{B}$ and $\mathrm{C}$ ) cows exposed to an estradiol-progesterone based protocol. (A) Buffaloes in Experiment 1 received PGF on days 8 and 9 of the protocol and treatments (PGF vs. control) were given on day 10. (B) Cows in Experiment 2 received PGF on days 7 and 8 of the protocol and treatments (PGF vs. control) were given on day 9. (C) Cows in Experiment 3 received PGF on day 7 of the protocol and treatments (PGF vs. control) were given on day 9 . 
(A) Dairy buffaloes

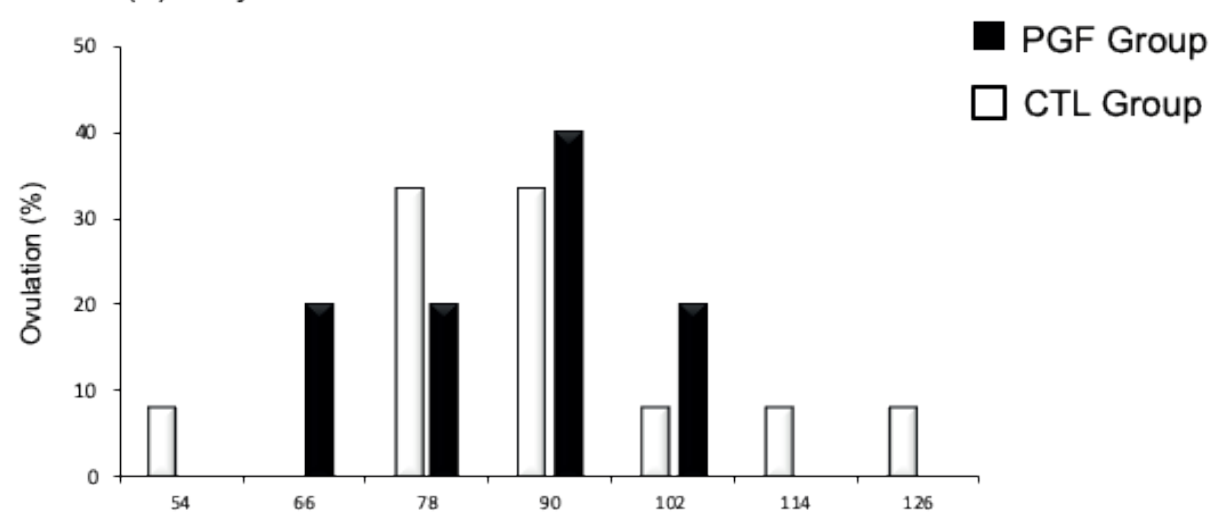

(B) Dairy cows

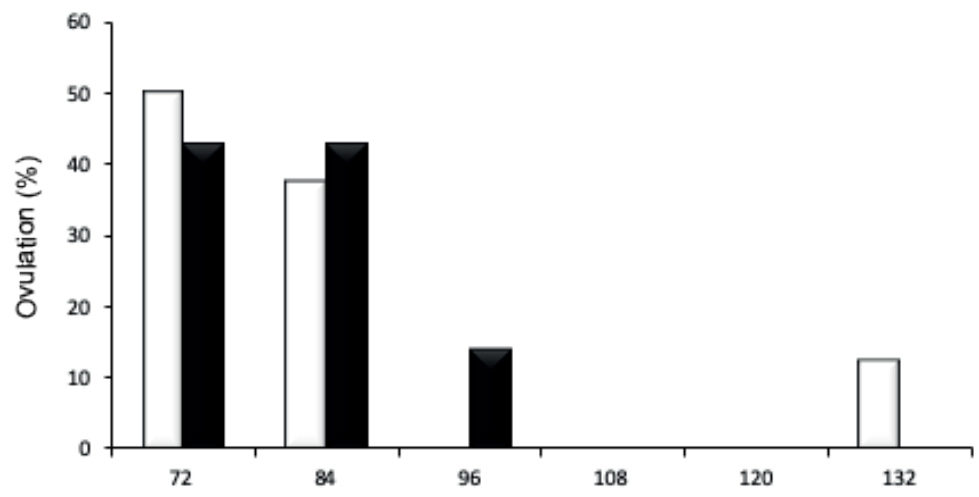

(C) Dairy cows

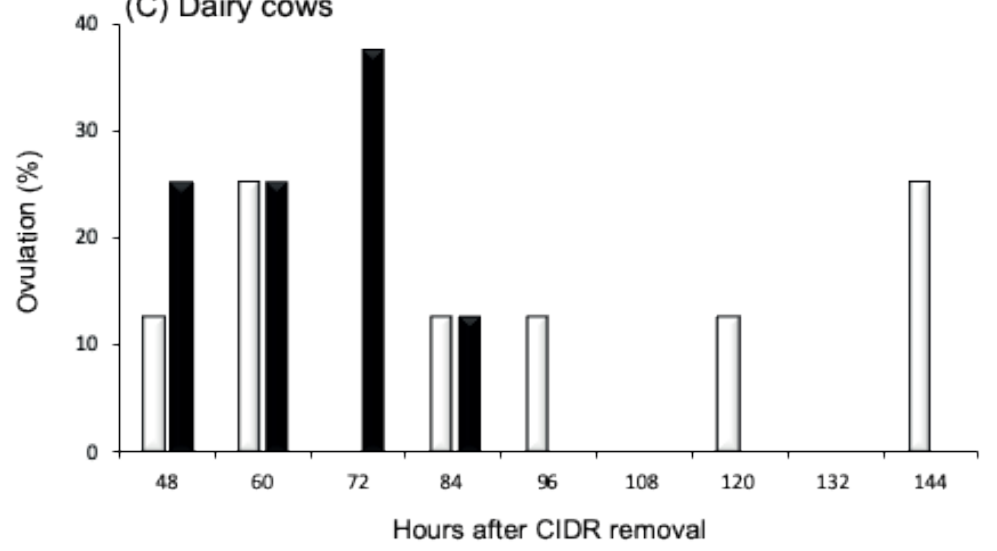

Figure 3. Distribution and percentage of ovulations, following an estradiol-progesterone based protocol, in (A) dairy buffaloes (Experiment 1); (B) dairy cows treated with at least 2 PGF injections on days 7 and 8 (Experiment 2); and (C) in dairy cows treated with at least 1 PGF injection on day 7 (Experiment 3). In all the experiments, cows received the treatment 24 hours after CIDR removal, and PGF treated cows were compared to controls. 


\section{Experiment 2}

The ovarian responses are shown in Table 1. Only one cow, from the PGF group, did not ovulate after CIDR removal. There was no difference between groups in the preovulatory follicle diameter $(P=0.79)$. Moreover, the progesterone concentration after CIDR removal was not different between groups $(P=0.68$; Figure $2 \mathrm{~B})$. Dairy cows in both experimental groups had a serum progesterone concentration below $1 \mathrm{ng} / \mathrm{mL} 48$ $\mathrm{h}$ after CIDR removal. The interval to ovulation $(P=0.69)$ and synchronized ovulation rate $(P=$ 0.9 ) were not different either between CTL and PGF groups. The distribution of ovulation is shown in Figure 3B. Most of the cows ovulated from 72 to $84 \mathrm{~h}$ after CIDR removal, whereas only one cow from the PGF group and one cow from the Control group ovulated $96 \mathrm{~h}$ and 132 $\mathrm{h}$ after CIDR removal, respectively (Figure $3 \mathrm{~B}$ ).

\section{Experiment 3}

The ovarian responses are shown in Table 1. All cows ovulated, and no difference was detected in the preovulatory follicle diameter between the CTL and PGF groups $(P=0.34)$. However, cows treated with PGF ovulated earlier than those in the CTL group $(P$ $=0.05$ ). As for the progesterone concentration after CIDR removal, it was not different between groups ( $P=0.70$; Figure $2 C$ ). Similar to what was observed in Experiment 2, dairy cows in both experimental groups were characterized by a serum progesterone concentration below $1 \mathrm{ng} / \mathrm{mL} 48 \mathrm{~h}$ after CIDR removal. Notably, the synchronized ovulation rate tended to be higher in cows treated with PGF, in which $75 \%$ of ovulations occurred in a synchronized manner $(P=0.1)$. In contrast, in the CTL group, only $37.5 \%$ of ovulations occurred in the same interval. The distribution of ovulation is shown in Figure 3C. The interval from the first to the last ovulation was $36 \mathrm{~h}$ (i.e., from 48 to $84 \mathrm{~h}$ ) in cows treated with PGF, whereas it was of 96 $\mathrm{h}$ (i.e., from 48 to $144 \mathrm{~h}$ after CIDR removal) in cows from the CTL group.

\section{Discussion}

The results of the current study partially support the hypothesis tested. The interval to ovulation and ovulation rate were not different between treatments in buffaloes (Experiment 1) nor in cows (Experiment 2) receiving PGF in days 7 and 8 of the protocol. However, cows treated with PGF but not receiving any on day 8 of the protocol (Experiment 3) ovulated earlier and more synchronously than control cows.

The identification and study of new molecules to induce ovulation could help introduce important alternatives to increase the use of reproductive biotechniques and, consequently, enhance the productivity of dairy cows and buffaloes raised in the Amazon biome. Increasing the milk production in this region is an important requirement, especially for smallholder farms, in which milk production is the main economic activity. Dairy cows and buffaloes raised in the Amazon biome are characterized by both a low productivity and low profitability. Although, the herd continues to grow in this challenging agricultural frontier, increasing milk yield and reproductive performance is still necessary to enhance the quality and productivity of the herd. As the overall results of the present experiments did not indicate an improvement in the ovarian response in cattle, seeking molecules that have a positive impact on livestock production is still necessary. 
In Experiments 1 and 2, all females were treated with at least 2 doses of PGF, 24 $\mathrm{h}$ before and at CIDR removal. Notably, the PGF treatment given $24 \mathrm{~h}$ after CIDR removal did not hasten the ovulation in dairy buffaloes and cows. Although not significantly different the ovulation range of control cows was more spread than that of PGF treated cows. It is well established that luteolysis is improved by the use of sequential doses of PGF, which increases the PIAI ratio in dairy cows subjected to TAl protocols (Borchardt, Pohl, Carvalho, Fricke, \& Heuwieser, 2018). This response is typically observed in cyclic cows with a newly formed CL. However, anovular dairy cows that received two sequential treatments with $P G F$ had an increased P/AI ratio compared with those receiving a single treatment with PGF (Pereira et al., 2015). To avoid this confounding factor in Experiment 3, cows were not treated with PGF at CIDR removal, and cows treated with PGF to induce ovulation ovulated earlier than control cows. This evidences the ovulatory effect of PGF in dairy cows. As for dairy buffaloes, however, further research is needed to test if PGF has the same effect.

The ovulation rate observed in buffaloes in the present study were lower than those observed elsewhere, such as 82.3\% (Baruselli, 1999), 93.3\% (Berber, Madureira, \& Baruselli, 2002), and $81.0 \%$ (Carvalho et al., 2005). However, these studies differed from the present one in that the latter was performed with dairy buffaloes from the Amazon biome. Furthermore, Martins, Oliveira, Ribeiro, \&Quirino, (2002), who used an estradiol-progesterone based protocol to induce ovulation in buffaloes in the State of Pará, Brazil, observed that 96\% of the cows ovulated after CIDR removal. Although the number of animals included in the present study is low, these evidences lead us to infer that PGF has no ovulatory effect in buffaloes. Previous studies have indicated that d-cloprostenol has an ovulatory effect similar to that of EB in TAI protocols, resulting in similar ovulation and pregnancy rates in dairy (Pfeifer et al., 2016; Castro et al., 2018) and beef cows (Pfeifer et al., 2014, 2018). Moreover, the injection of PGF has also been reported to act as an ovulatory stimulus in prepubertal heifers (Pfeifer et al., 2009; Leonardi et al., 2012). These studies support the hypothesis that PGF can induce ovulation of the dominant follicle by an independent mechanism of luteolysis. Despite this, the mechanism of action of exogenous PGF to trigger ovulation in cattle is still unknown. Several studies have attempted to understand how PGF stimulates ovulation (Randel, Lammonglia, Lewis, Neuendorff, \& Guthrie, 1996; Naor et al., 2007; Fortune, Willis, Bridges, \& Yang, 2009). It has been suggested that PGF exerts a direct effect on the anterior pituitary (Weems et al., 2006), which increases pituitary responsiveness to $\mathrm{GnRH}$ and thereby enhances the release of LH (Randel et al., 1996). Moreover, PGF also appears to play a local role in the ovary. Prostaglandins $\left(\mathrm{PGE}_{2}\right.$ and $\mathrm{PGF}_{2} \alpha$ ) secreted by the granulosa cells (Evans, Dobias, King, \& Armstrong, 1983; Bridges \& Fortune, 2003) are closely linked to the ovulatory process (Murdoch, Hansen, \& Mcpherson, 1993). Our recent experiment, in which ovariectomized cows were treated with a PGF analogue (d-cloprostenol), a $\mathrm{GnRH}$ analogue (buserelin acetate), or saline, demonstrated that only cows treated with $\mathrm{GnRH}$ had increased plasma LH concentration after treatment (unpublished data). Moreover, when PGF was used as an ovulatory stimulus in dairy cows, an association between follicle vascularization and the interval to ovulation was observed (Pfeifer et al., 2016). These 
results led us to further hypothesize that PGF, acting mainly via a local mechanism, requires a higher developmental status of pre-ovulatory follicles compared to the systemic-mediated action of ECP.

In cows, progesterone concentrations had decreased to less than $1 \mathrm{ng} / \mathrm{mL} 48 \mathrm{~h}$ after the PGF treatment. No effect of group was detected in progesterone concentrations after CIDR removal in any of the 3 experiments. These results demonstratethat treatmentgroupswere under the same progesterone environment at the time of the ovulatory treatments. Although, no differences in the interval to ovulation between groups were detected in Experiments 1 and 2,87.5\% of the cows in the CTL group from Experiment 2 ovulated synchronously, despite no differences in progesterone concentrations between groups and experiments. Moreover, the absence of the PGF injection on day 8 in Experiment 3 resulted in PGF hastening ovulations, whereas no effect of PGF was observed when PGF was injected on day 8 of the protocol. As the drop in progesterone concentrations after CIDR removal in Experiments 2 and 3 were very similar, we can infer that this was not the cause of the observed differences. Collectively, these results indicate that PGF indeed causes ovulation independently of its luteolytic effect. In buffaloes, however, the progesterone concentrations were already low at CIDR removal. Another study has demonstrated that reduced doses of PGF promote luteolysis and induce estrus in buffaloes (Chohan, 1998), evidencing the high sensitivity of the CL of buffaloes to PGF treatment.

Finally, the results from Experiment 3 show that PGF given $24 \mathrm{~h}$ after CIDR removal, is able to hasten ovulation in cows, but not in dairy buffaloes. Notably, the effect of PGF after CIDR removal has previously been studied (Gabriel, Wallenhorst, Dietrich, \& Holtz, 2011; GarciaIspierto, \& Lópes Gatius, 2014; Ambrose, Gobikrushanth, Zuidhof, \& Kastelic, 2015), but the difference with the current study is that PGF was injected at TAI. A study reported that the treatment with PGF did not affect pre-ovulatory follicle diameter, CL size, nor progesterone levels (Neglia et al., 2012). In contrast, Neglia et al. (2008) observed a significantly larger CL on day 10 after $\mathrm{Al}$, along an increase in whey progesterone concentration, in buffaloes treated with cloprostenol on the day of Al. Overall, the study of new molecules that induce ovulation is particularly important in the buffalo due to its reproductive peculiarities, such as a variable duration of estrus, namely between 4 and $64 \mathrm{~h}$, which complicates the prediction of the moment of ovulation (Baruselli, 2001). Considering that two Al procedures is a common practice in buffaloes, an effective ovulation inducer could overcome this issue and increase the potential for a single successful $\mathrm{Al}$, using a single straw of semen (Neglia et al., 2008).

\section{Conclusion}

The present study provides important data on the use of PGF as an ovulatory stimulus for TAl programs in dairy crossbred cows. In contrast, similar effects were not observed in dairy buffaloes. Collectively, it is plausible that a pre-ovulatory treatment with PGF might have benefits for the synchronization of ovulation in dairy cows beyond its direct effects on luteal regression, as its effects were independent of changes in serum progesterone concentrations. 


\section{References}

Algire, J. E., Srikandakumar, A., Guilbault, L. A., \& Downey, B. R. (1992). Preovulatory changes in follicular prostaglandins and their role in ovulation in cattle. Canadian Journal of Veterinary Research, 56(1), 6769.

Ambrose, D. J., Gobikrushanth, M., Zuidhof, S., \& Kastelic, J. P. (2015). Low dose natural prostaglandin $\mathrm{F} 2 \alpha$ (dinoprost) at timed insemination improves conception rate in dairy cattle. Theriogenology, 83(4), 529-534. doi: 10.1016/j. theriogenology.2014.10.034

Avenell, J. A., Seepudin, Y., \& Fletcher, I. C. (1985). Concentrations of $\mathrm{LH}$, oestradiol $17 \beta$ and progesterone in the peripheral plasma of swamp buffalo cows (Bubalus bubalis) around the time of oestrus. Journal of Reproduction and Fertility, 74(2), 419-424. doi: 10.1530/jrf.0.0740419

Baruselli, P. S. (1999) Inseminação artificial em tempo fixo com sincronização da ovulação em bubalinos. In H. Tonhati, V. H. Barnabé, \& P. S. Baruselli (Eds.), Bubalinos: sanidade, reprodução e produção (pp. 126-142). Jaboticabal: FUNEP.

Baruselli, P. S. (2001). Control of follicular development applied to reproduction Biotechnologies in buffalo. Proceeding of the Congresso Nazionale Sull'allevamento del Búfalo, Eboli, SA, Itália, 1.

Baruselli, P. S., \& Carvalho, N. A. T. de. (2005). Biotecnologias da reprodução em bubalinos (Bubalus bubalis). Revista Brasileira de Reprodução Animal, 29(1), 4-17.

Berber, R. C. A., Madureira, E. H., \& Baruselli, P. S. (2002). Comparison of two ovsynch protocols (GnRH vs. LH) for fixed timed insemination in buffalo (Bubalus bubalis).
Theriogenology, 57(5), 1421-1430. doi: 10.1016/s0093-691x(02)00639-8

Borchardt, S., Pohl, A., Carvalho, P. D., Fricke, P. M., \& Heuwieser, W. (2018). Short communication: effect of adding a second prostaglandin $\mathrm{F} 2 \alpha$ injection during the Ovsynch protocol on luteal regression and fertility in lactating dairy cows: a metaanalysis. Journal of Dairy Science, 101(9), 8566-8571. doi: 10.3168/jds.2017-14191

Bridges, P. J., \& Fortune, J. E. (2003) Progesterone mediates gonadotrophin induced secretion of prostaglandins $E$ and F2a (PGE, PGF) by follicular cells from bovine preoculatory follicles. [Abstract] Biology of Reproduction, 68(Suppl 1), 47.

Bridges, P. J., \& Fortune, J. E. (2007). Regulation, action and transport of prostaglandins during the periovulatory period in cattle. Molecular and Cellular Endocrinology, 263(1-2), 1-9. doi: 10.1016/j. mce.2006.08. 002

Camelo, A. S. A., Ribeiro, H. F. L., Silva, A. O. A., Souza, J. S., \& Vale, W. G. (2002). Pregnancy rates in suckled female buffaloes submitted to estrous and ovulation synchronization with artificial insemination in fixed time. Proceeding of the Buffalo Symposium of Americas, Belém, PA, Brasil.

Carvalho, N. A. T., Carvalho, M. V., Visintin, J. A., Vannucci, F. S., Sá, M. F., Fo., Nichi, M.,... Baruselli, P.S. (2005). Uso de dispositivos intravaginais de progesterona associados ao hCG ou $\mathrm{GnRH}$ para sincronização da ovulação em búfalas na estação reprodutiva desfavorável. Anais do Congresso Brasileiro de Reprodução Animal, Goiânia, GO, Brasil.

Carvalho, N. A. T., Nagasaku, E. M., Vannucci, F. S., Toledo, L. M. \& Baruselli, P. S (2007). Ovulation and conception rate according 
intravaginal progesterone device and hCG orGnRHtoinduceovulationinbuffaloduring the off breeding season. Italian Journal of Animal Science, 6(2), 646-648. doi: 10. 1016/j.theriogenology.2016.09.006

Castro, N. A., Neves, P. M. A., Cestaro, J. P., Melo, V. T. O., Schneider, A., \& Pfeifer, L. F. M. (2018). Use of prostaglandin F2alpha as ovulatory stimulus for synchronizing dairy cattle. Research in Veterinary Science, 118, 151-154. doi: 10.1016/j. rvsc.2018.01.010

Cavalieri, J., Hepworth, G., Parker, K. I., Wright, P. J., \& Macmillan, K. L. (2003). Effect of treatment with progesterone and estradiol when starting treatment with an intravaginal progesterone releasing insert on ovarian follicular development and hormonal concentrations in Holstein cows. Animal Reprodutcion Science, 76(3-4), 177-193. doi: 10.1016/s03784320(02)00260-9

Chohan, K. R. (1998). Estrus synchronisation with lower dose of PGF2 $\alpha$ and subsequent fertility in subestrous buffalo. Theriogenology, 50(7), 1101-1108. doi: 10.1016/s0093-691x(98)00211-8

Evans, G., Dobias, M., King, G., \& Armstrong, D. (1983) Production of prostaglandins by porcine preovulatory follicular tissues and their roles in intrafollicular function. Biology of Reproduction, 28(2), 322-328. doi: 10.1095/biolreprod28.2.322

Fortune, J. E., Willis, E. L., Bridges, P. J., \& Yang, C. S. (2009). The periovulatory period in cattle: progesterone, prostaglandins, oxytocin and ADAMTS proteases. Animal Reproduction, 6(1), 60-71.

Gabriel, H. G., Wallenhorst, S., Dietrich, E., \& Holtz, W. (2011). The effect of prostaglandin $\mathrm{F}$ (2alpha) administration at the time of insemination on the pregnancy rate of dairy cows. Animal Reproduction
Science, 123(1-2), 1-4. doi: 10.1016/j. anireprosci.2010.11.010

Garcia, A., \& Salaheddine, M. (2001). Effect of oestrous synchronization with estradiol $17 \beta$ and progesterone on follicular wave dynamics in dairy heifers. Reproduction in Domestic Animals, 36(6), 301-307. doi: 10.1046/j.1439-0531.2001.00306.x

Garcia-Ispierto, I., \& Lópes Gatius, F. (2014). Effects of different five-day progesterone based fixed time Al protocols on follicular/ luteal dynamics and fertility in dairy cows. Journal of ReproductionandDevelopment, 60(6), 426-432. doi: 10.1262/jrd.2014063

Ginther, O. J., Knopf, L., \& Kastelic, J. P. (1989). Temporal associations among ovarian events in cattle during o estrous cycles with two and three follicular waves. Journal of Reproduction and Fertility, 87(1), 223230. doi: 10.1530/jrf.0.0870223

Instituto Brasileiro de Geografia e Estatística (2016). Base de dados agregados SIDRA. Pesquisa da Pecuária Municipal. Recuperado de http:// www.sidra.ibge. gov.br

Kanai, Y., \& Shimizu, H. (1983). Characteristics of the estrous cycle of the Swamp buffalo under temperate conditions. Theriogenology, 19(4), 593-602. doi: 10.1016/0093-691x(83)90179-6

Kanai, Y., Abdul-Latief, T., Ishikawa, N., \& Shimizu, H. (1990). Behavioural and hormonal aspects of the oestrous cycle in swamp buffaloes reared under temperate conditions. Proceedings of the Domestic Buffalo Production in Asia, Vienna, Austria.

Leonardi, C. E. P., Pfeifer, L. F. M., Rubin, M. I. B., Singh, J., Mapletoft, R. J., Pessoa, G. A.,... Silva, C. A. M. (1012). Prostaglandin F2 $\alpha$ promotes ovulation in prepubertal heifers. Theriogenology, 78(7), 1578-1582. doi: 10.1016/j.theriogenology.2012.06.030 
Madan, M. L., \& Prakash, B. S. (2007). Reproductive endocrinology and biotechnology applications among buffaloes. In J. L. Juengel, J. F Murray, \& M. F, Smith (Eds.), Reproduction in domestic ruminants VI. Nottingham, UK: Nottingham University Press.

Martinez, M. F., Kastelic, J. P., Bo, G. A., Caccia, M., \& Mapletoft, R. J. (2005). Effects of oestradiol and some of its esters on gonadotrophin release and ovarian follicular dynamics in CIDRtreated beef cattle. Animal Reproduction Science, 86(1-2), 37-52. doi: 10.1016/j. anireprosci.2004.06.005

Martins, R. P., Oliveira, F. F. de, Ribeiro, H. F. L., \& Quirino, C. R. (2002). Estrous induction and synchronization using Crestar $^{\circledR}$ in buffaloes in the Para state, Brazil. Proceeding of the Buffaloes Symposium of Americas, Belém, PA, Brasil, 1.

Melo, L. F., Monteiro, P. L. J., Jr., Surjus, R. S., Drum, J. N., Wiltbank, M. C., \& Sartori, R. (2016) Progesterone-based fixed-time artificial insemination protocols for dairy cows: Gonadotropin-releasing hormone versus estradiol benzoate at initiation and estradiol cypionate versus estradiol benzoate at the end. American Dairy Science Association, 99(11), 9227-9237. doi: 10.3168/jds.2016-11220

Murdoch, W. J., Hansen, T. R., \& Mcpherson, L. A. (1993). A review - role of eicosanoids in vertebrate ovulation. Prostaglandins, 46(2), 85-115. doi: 10.1016/0090-6980 (93) $90037-8$

Naor, Z., Jabbour, H. N., Naidich, M., Pawson, A. J., Morgan, K., Battersby, S.,... Millar, R. P. (2007). Reciprocal cross talk between gonadotropin-releasing hormone $(\mathrm{GnRH})$ and prostaglandin receptors regulates $\mathrm{GnRH}$ receptor expression and differential gonadotropin secretion. Molecular Endocrinology, 21(2), 524-537. doi: 10.1210/me.2006-0253

Neglia, G., Natale, A., Esposito, G., Salzillo, F., Adinolfi, L., Campanile, G.,... Zicarelli, L. (2008). Effect of prostaglandin F2alpha at the time of $\mathrm{Al}$ on progesterone levels and pregnancy rate in synchronized Italian Mediterranean buffaloes. Theriogenology, 69(8), 953-960. doi: 10.1016/j.theriogeno logy.2008. 01.008

Neglia, G., Vecchio, D., Russo, M., Di Palo, R., Pacelli, C., Comin, A.,... Campanile, G. (2012). Efficacy of PGF(2alpha) on preovulatory follicle and corpus luteum blood flow. Reproduction in Domestic Animals, 47(1), 26-31. doi: 10.1111/j.1439-0531. 2011.01794.x

Oliveira, J. V. L., Ribeiro, A. de L., F'., Vale, V. R., $F^{\circ}$., Andrade, V. J., Quirino, C. R., Salvador, D. F.,... Gusmão, A. L. (2001). Efeito da dosagem hormonal sobre a fertilidade e a função luteal de vacas zebus sincronizadas com combinação de GnRH e Prostaglandina. Revista Brasileira de Reprodução Animal, 25(3), 323-325.

Pereira, M. H. C., Wiltbank, M. C., Barbosa, L. F. S., Costa, W. M., Jr., Carvalho, M. A. P., \& Vasconcelos, J. L. M. (2015). Effect of adding a gonadotropin-releasinghormone treatment at the beginning and second prostaglandin $\mathrm{F} 2 \alpha$ treatment at the end of an estradiol-based protocol for timed artificial insemination in lactating dairy cows during cool or hot seasons of the year. Journal of Dairy Science, 98(2), 947-959. doi: 10.3168/jds.2014-8523

Perera, B. M. A. O. (2011). Reproductive cycles of buffalo. Animal Reproduction Science, 124(3-4), 194-199. doi: 10.1016/j. anireprosci.2010.08.022 
Pfeifer, L. F. M., Leonardi, C. E. P., Castro, N. A., Viana, J. H. M., Siqueira, L. G. B., Castilho, E. M.,... Rubin, M. I. B. (2014). The use of PGF $2 \alpha$ as ovulatory stimulus for timed artificial insemination in cattle. Theriogenology, 81(5), 689-695. doi: 10.1016/j.theriogenology.2013.11.016

Pfeifer, L. F. M., Rodrigues, W. B., Casanova, S. K., Anache, N. A., Castro, N. A., Castilho, E. M., \& Nogueira, E. (2018). Different protocols using PGF2alpha as ovulation inducer in Nelore cows subjected to estradiolprogesterone timed $\mathrm{Al}$ based protocols. Theriogenology, 120, 56-60. doi: 10. 1016/j.theriogenology.2018.06.030

Pfeifer, L. F. M., Siqueira, L. G., Arashiro, E. K., Castro, N. A., \& Viana, J. H. M. (2016). Prostaglandin $\mathrm{F} 2 \alpha$ or estradiol benzoate to induce ovulation in timed artificially inseminated dairy cows. Pesquisa Agropecuária Brasileira, 51(6), 738-744. doi: 10.1590/S0100204X2016000600005

Pfeifer, L. F. M., Siquira, L. G., Mapletoft, R. J., Kastelic, J. P., Adams, G. P., \& Colazo, M. G. (2009). Effects of exogenous progesterone and cloprostenol on ovarian follicular development and first ovulation in prepubertal heifers. Theriogenology, 72(8), 1054-1064. doi: 10.1016/j. theriogenology.2009. 06.022

Piketty, M. G., Poccard-Chapuis, R., Veiga, J. B., \& Tourrand, J. F. (2002). Cattle ranching in the Amazon rainforest, Animal Production in Australia, 24, 253-256.

Randel, R. D., Lammonglia, M. A., Lewis, A. W., Neuendorff, D. A., \& Guthrie, M. J. (1996). Exogenous PGF(2)alpha enhanced GnRHinduced $\mathrm{LH}$ release in postpartum cows. Theriogenology, 45(3), 643-654. doi: 10.1016/0093-691X(95)00410-A
Rawlings, N. C., Jeffcoate, I. A., \& Rieger, D. L. (1984). The influence of estradiol- 17beta and progesterone on peripheral serum concentrations of luteinizing hormone and follicle stimulating hormone in the ovariectomized ewe. Theriogenology, 22(5), 473-488. doi: 10.1016/0093$691 \times(84) 90047-5$

Rolim, S. T., Fo., Ribeiro, H. F. L., Vale, W. G., Picanço, N. S., Barbosa, E. M., \& Ferreira, R. N. (2009). Desempenho reprodutivo de fêmeas bubalinas criadas em sistema misto (várzea e pastagem artificial) no estado do Pará. I. Idade a primeira cria, intervalo entre partos, época de parição, eficiência reprodutiva e taxa de prenhez. Revista Ciência Animal Brasileira, 10(3), 754-763.

Roy, K. S., \& Prakash, B. S. (2009). Plasma progesterone, oestradiol-17 $\beta$ and total oestrogen profiles in relation to oestrous behaviour during induced ovulation in Murrah buffalo heifers. Journal of Animal Physiology and Animal Nutrition, 93(4), 486-495. doi: 10.1111/j.14390396.2008.00830.x

Silva, M., \& Reeves, J. J. (1985). Indomethacin inhibition of ovulation in the cow. Journal of Reproduction and Fertility, 75(2), 547549. doi: 10.1530/jrf.0.0750547

Statistical Analysis System Institute [SAS Institute] (1998).

Weems, C. W., Weems, Y. S., \& Randel, R. D. (2006). Prostaglandins and reproduction in female farm animals. Veterinary Journal, 171(2), 206-228. doi: 10.1016/j. tvjl.2004.11.014 